\title{
THE PINEYS
}

\section{Part One}

It's just that easy for Pineys to get into the White House. One's always waiting for the last one to be leaving And there's always one in the hall with his toes showing. Old Scratching Dogs have secret rooms and closets And the Great Dun Cocks have puzzling limestone tunnels That twist quietly under the kitchens and studies

But only Pineys have easy and even passage

To all the floors and stray with a laxity

Unheard of by wives and queasy secretaries.

Pineys have chewed their way in at every quadrenniel And gorged like pigs, or like rabbits, in each leafy ageThe age of beautiful trees when the undulant colonel

Extracted white worms from his breast and birds from his fingers, The age of lambs when the lustrous clint-shouldered ecstatic Carved heteroclite aspects and nodes in the crankled slime-beams, The age of the three muck eggs, the rotting triplets

Of slime and mold and moss, each an extinction, And the age of the halo, age of the holy pumpkin, Jack-o'-the blue, iceblink, last o' the Georges. They foraged about in each of the pretty stages Between the biblical war and the crocodile war, From Lincoln's death to Hanna's death, the blossoming: When Hayes, "Our Fraud" enchased in his peaceful forehead, Took up, for his own, the tender bloodless regalia, When Cleveland the mule preserved his thunderous virginity, When Grant, the great back turned, fell over the fleshpots, And McKinley, glorious, swollen, embalmed McKinley, Opened his mouth, and moved his arms, and spoke. The strain reaches back to the fleshy cannibal days Of Polk and Sarah Polk, Major Lewis, Major Eaton And the drinking ladies of Washington and Richmond. The furniture crashed with wit and there were Pineys 
Roaring in stately chintz and dimity

When the English Republic of Pickering and Griswold

Destroyed the musical peace of President Jefferson.

Even when the poor squabbling Fathers coupled off to provide

Whole miles, like an ocean, for the new capital

And eighty wild acres for the president's palace

In the excitement of the first extravagant scramble

To appease the convulsive states, the Pineys collected

Outside the Federal chambers exploring the venture

With delicate interest as the peril varied.

Caught again and again, they have faded and sunk

For years in the ugly lettered streets and have risen

At weddings, at dinners, in the good or gentle circles

Taking their places along with the oldest and saddest.

There in the giant State rooms or out in the butchered

Extensions bulging with chattering crones and suckers

Their wheeling combines with the general wheeling and flapping.

They never seem to grow tired of the greedy clatter

Nor want to take flight nor dream, at least, of flying,

Like most forgotten journeymen and henchmen,

Voluptuously back at the last to certain dear rivers

Where they can search over the beauty of their own departures

And study their portions in softness and distinction-

Or if they do the rivers, or ponds, must be dreary,

The meadows and forests flustered and vaporous

And the dream itself a feeble abstract dream

Which they, out of kindness, put a keen face upon,

Hugging their "bitter heads" and "flashing their hobbles"-

They are so released, it seems, from that kind of fever.

2

The builder, the despot, fresh from the comforting square

And the allegorical fountain, or broken in two

By the mirrors and astral lamps, or blighted, or almost

Blessed by the dripping larches, or gathering leeches,

Or gathering leeches or fishing for ichthyosaurs,

The cunning based on pre-Islamic terror, 
Or pan-seraphic or proto-Socratic squalor,

Or back in clumsy triumph or down in tears,

Rejected forever at Wormleys and Little Welchers,

Or now at the crowded cheese or now in the lepers'

Floating meathouse, the tender despot or grinder

Nuzzles his way through the wreckage, or sanctified, or gelded,

As the case may be, converts or muffles the scourges.

For one good hour, fresh from the varnished fruit

And the matching candelabra or lightly rent

By the plump indecent Maenads, he finds his labor,

Even his failure, in true or good concordance

With the pretty sight of himself in the oxygen garden

Or naked between the gory elms or sweetened

With grief or kind and ascetic or old and erotic

He has, or had, at the time of the one hopeful space

Between the levitation and the first prostration.

The Lord being cold to him, or savage or subtle,

He gathers by every greedy device he knows

His comforts about him and struggles like brutal Plato

Or brutal Hegel or cheerful suffering Hegel

To overcome through queer abandonment

Or queer abstraction the infelicity,

Or in a fit of elevation he rises

On even demented and unconnected wings,

Or in a fit of irony he hides

His vertigo behind obsequious falls,

Or in a fit of vanity he drags

His bastard stringers in consoling circles,

Or smears the scalls with blood, or dips them in acid,

Or sulphur, or lime, whatever the labor of purity.

My own labor of purity is no less nominal,

In its way, and no less fitful and no less brittle

Than this or the other fertile purity constructs

That $\mathrm{I}$, in my own craze of luxury, can convolve.

The wildest ones, from Roman pacifists on Spring Street 
To deaf Orthodox Jews on Baynton Street

To a roomful of wolves at the Hotel Benjamin Franklin, Are each, as in my astriction, lovably stretched

In a glut of muscle, with conflux, poor or wise, But squeezed in their own as I in my astriction. It would be peace, it would be the good abatement,

To find in each extinction its living thing,

To find in the wolves, the Orthodox Jews and the Romans,

To find in the blastoderm and the wild centauri,

The Massachusetts red pine, the Georgia, the Florida blue pine,

Their own fertilities, in their spaces bony

Or fleshy or spongy, in the one place hylic, in the next

A limp platonic; stony luminous; heartless;

Each a plighting, a plashing, on the ripe occasion,

A raging, of those that rage, and less of it those

That rage less, all with their own inculpable quavers,

And these as ungodly, oh as ungodly somehow as possible,

As sweetly visible, when visible, as deadly visible,

As undistorted; peace, peace not to cement

The leaf to the maid, the wind to the studded leaf,

The wolf to a yoke, the Roman to a yoke-to a thing,

To a lowness, a pressure, (a pinning) but not to a yoke,

To a clasp, (a friction, a passion) but not to the dear

Damp clog of a yoke-peace oh not to confuse

A summer's nutriment drawn back into stem and root

And the complex exchange of chlorophyll for carotin

With October's fire and the kindling of autumn's trees,

And not to confuse the shoreline and its grand shifting

With man's upheaval and man's upheaval and the huge

Vague savory waves with God's vague savory fingers,

And peace to find, to be found, to be flooded by a nexus

Where all the living things are living, none dying,

But by their own deaths, but by their unspeakable deaths,

And peace, peace, in the states of great hate and great love,

Where the eyes turn in upon themselves breeding demons

And only a venomous whiteness is given in the world,

It would be peace, at the birth, at the growth, at the whitening,

To be so circled, to be so lucidly circled 
At each laceration that even the time of least blood And little or no elevation, the time of ugly Tissueless knowledge, poverty knowledge, painful Ungoverned spaces, cracked and split and slackened, They either are harsh, they either are harsh, they either Are grinding out life with their palms and knuckles, they either Are pounding it with their hams, they either are pushing And crushing it with their shoulders and backs, they either Are screaming and snarling or you are suffering from a richness.

It would be peace, it would be the dear abatement

To find in each variation mad eyes and ears And an amorous nose and tender surging lips, To find in my own, to find in my thirty-five years Of eating and drinking and thinking, including the years Of the dove and the years of the gull and the years of the crowAt the mouth, at the breast-standing in their ways for stages Strident, resonant, sibilant, stages milky, stages fleshy, Stages pulpy, the ridges and ribs of my life from the year Of stress to this or that height, this love, that limbo, A misery of limbos, the cellars alone in three states And even two countries, the schools alone in eight cities, In half of Europe; the schools; Minerva, Minerva, The moon on the grass and the statue and the bookstore of love, On the green green green green grass from torturous Lee At the very first to Temple, your bunny, Minerva, Your baby, which out of the wisdom good Johnny Ring kindled And Johnny's good master, Old Acres, not only abstracts As its own your godhood but filches your animal, Knowing (in the depths of College and Carnell and Conwell) The owl's pure logic, its silent reflective flight And its entrance in all your complexity, dear old holy, The owl, the Great Fudge Owl, the Fag Owl, the Booster Owl, The Rat Owl, the Massachusetts Rat Owl, the Carolina Rat OwlAnd green, the green green green from Taylor Allderdice, From Pitt, colossal shepherd, from Colfax, from Chadir, From room to room, from Lake Grove, from dreary Columbia, A student, a teacher, a student, a teacher, from wept on To wept at to wept on to wept at, from Glasgow, from Paris, 
From Florence; from Karnak, from Luxor; from Thebes; the tissue Of opulence, snow and rain and a dense metaphysic, Including my old gothic hate and my old gothic anger And my love of flame and fire and burning incandescence, Without dragging a thousand dead gods to the slaughter. 


\section{Part Two}

I saw the Piney at first as merely a stray Historical mixture, some lopsided fault, Like the pure product of America gone crazy,

Or something out of Faulkner or Caldwell that touches

Our lower hearts but later I saw this line

Was much too primitive to do them justice.

They are not in any proper sense a people

With their own language and their own place of origin

Or something to hold them together like war and religion,

Yet they remain a kind of perfect passion

For the old lurists of Philadelphia and Camden.

The WPA Guide of 1939

Described them as inbreds brought together by defeat

And poverty and living-as they put it-in hovels

Of cast-off boxes and miscellaneous lumber.

It is a short and unsuspicious statement

And doesn't mix in too much fear and poetry.

It traces them back to religious outcasts, Tories,

British deserters, revelers, impoverished immigrants,

And gangs of thieves who terrorized the countryside.

Like all the other guides it finds its source

In the writing of Elizabeth Kite, a Vineland worker,

Who was the first to publicize the name

And give a solid direction to the myth.

Kite's work was published in The Survey,

A little weekly of American philanthropy.

It is a flowery, almost violent article,

Complete with graphs and tables and gruesome photographs.

She saw them simply as a degenerate group

Living in isolation and promiscuity.

She called them "Pine Rats" and saw them as a people

With a separate manner of life and a separate soul.

She was obsessed with "lines" and though she paid

Lip service to the new theory of environment

Her real loyalty was to the theory of blood. 
She does three things: first she pulls them together,

Then she draws a picture of their origin,

Then she moves like a hammer through their wilderness.

In the style of I9I 3 she had a sense

Of an absolute line between the saved and the damned

And this is what gave her her clean sense of direction.

To her the Pineys are either demented branches

Of healthy trees, related by sick blood

To decent families, or demented heirs

Of the original outcasts, or a final glut

Of the old industry that blossomed in the Pines.

In the first case she shows what happens when stray

Shoots are taken out of their natural home

And stands in horror at the honest names

Scattered about like rubbish in the woods;

In the second case she traces the Piney back

To what by now is almost a classic source:

Quaker sensualists driven out of the fold,

Debtors and bankrupts looking for darkness, weasels

Beating the law, deviates, dissenters, little colonies

Of thieves, babbling Hessians, Loyalists, moved by shame

And fear, and drunkards and sadists and gluttons

From Brother Bonaparte's court in Bordentown;

And in the third she draws them out of the history

Of the old kingdom of charcoal and iron-the remnant

Of the ticket-men who grubbed like dogs for the rich

And lived in little black towns around the furnaces;

But most of the article is taken up with a study

Of morons and moron trees as if a sure

Connection existed between the state of their birth

And an I.Q. test-and unemployment and fondling.

According to Kite the Piney is lazy and cunning,

A degenerate creature who has learned to provide for himself

Only the stupid necessities of life

Without entering into the stimulating struggle.

She compares him to the crab that gave up its freedom

And built a wall of defense around itself

By gluing its head to a rock and spending its life 
Kicking food into its mouth and reproducing. She calls him a barnacle upon our civilization Whose higher functions have atrophied through disuse, And over and over again she returns to the sexual With all the compulsion of an auto-erotic. Beck, Weygandt, and all the other lurists Follow the disconnected lead of Kite. Henry Goddard, Kite's immediate boss, Based his whole theory of the Kallikaks On Kite's work-only Miles Feinstein, A former honors student at Rutgers College (And later McPhee, after this poem was written) Take a kinder, and saner, look at the Pineys.

-I think it was the natural hatred of law And the simple love of space that led to the myth; I think it was the dream of bankruptcy And the almost queer addiction to the nightmare; And I think it was the three great things: a wilderness Of seven counties, of over a million acres, Just on the border of megalopolis, And a whole chaos of heavy industry Buried in the woods or turned into a museum, And a whole world of childlike or dreamlike people Just out of reach of our greedy sensitive minds. In 1800 the Pines were the major center Of iron production in the United States And the complex life of New York and Philadelphia Depended on the energy of the Pines. Batsto was the Pittsburgh and Quaker Bridge Was the resting point between McKeesport and Weirton. By I 850 the age of iron was over And only little puffs of paper and glass Were able to move the intellect of the bankers. By I900, except for the bloody cranberry And a little scattered pulp, the work was ended. Today the Pines are more like they were in $17-$ oo than they were in I 830, the peak Of the culture-meaningless roads dead end in the woods 
And meaningless fires burn between the barriers. A few city blocks from Batsto the trees take over And the Batsto River makes its first sharp bend. Southeast of Chatsworth, the Plains, the two islands Of dwarf vegetation, like two little stricken hearts, Still stand as they did in the beginning of the eighteenth century Without any real change in growth or borders. Only the threat of jetports and subdivisions, Like dull music from the north, disturbs the order. Those who are "Pineys" make a living on the roads And the gas stations, or rent themselves out as guides, And harvest a little wood and pick berries. At their peak they worked the back of the season, Pulling moss, gathering greens and flowers, Picking pine balls, digging roots and plants, And a few still float through the woods like the burnt grandfathers, But the main harvesting is done by Puerto Ricans And defrauded Blacks trapped in the yellow buses. Here and there a broken drain pipe remains And rusted cans and cars jacked up on blocks, But only as a cracked reflection of the dream. Everyone who saw them found a little identity According to his own intelligence and buffoonery And they were used as the poor are always used, Both to be the impoverished and to pay the debt. Myself I am a phantist finding in their lives An intense connection with my own severance. 


\section{Part Three}

What still remains is identity with the wordAnd "Pineys" are those who hang together in the word, (Or "Piney" is one who re-embodies in the word), And responds (respond) in anger or humor or silence, Presenting to the world outward a knot of possession Whose nature is unique and reluctantly secretive, As in the other human communities or categories. - I first came across the term in 1958 In one of those Sunday Bulletin magazine articles; I was struck immediately by the power of the uses And walked around violent half the night in Logan. I was also struck at once by the foolish uses And frozen by the sense of absurdity and impracticality, Though at the beginning the doubt still left some room For the mind uncharneled to work its cadaverous fits. They were, as I saw them then, a maximum image For that which exists as black, destructive and cunning, And much more efficient than wolves, spiders, elephants, And the other brutal tokens of the forties and fifties. I set up the two great poles, the White House, on the one hand, As the source of order, intelligence, love and restraint And the Pineys the source, as I say, of the dark and destructive, Or, seen in the light of poles, the Pineys as token Of that unnamed but existing-the Black House?-a fountain Or seat, location-original, radical, tenaciousIf that is the case, or merely (merely?) a point Of reference, a shoulder of action (or bum) in the larger, In the whiter, an isolation, an extrapolation, And not a true fountain, and not a true resting point, Whatever the nature is of fountains and resting points. Part of the problem lay in the lack of true opposites And part of the problem lay in my own indecision, Or what is the same, my constant shift in knowledge. The White House (refer to as $\mathrm{x}$ ), as it is token 
And focus of all ministration contains in its pains, And as a link in its pains, integral and defining, That which, by consent, I ascribe to the Pineys Who, as a part of the pains, a side of the mystery, Cannot, for the sake of decent logic, "oppose" it. As far as the noumenal White House-crystal or gas(Refer to as $y$ ), it is a projection of $x$ (Or if you prefer, $x$, not $y$, is projected) And therefore there cannot be a parallel opposite Projection of the Pineys ( $z$ ) to equate with y, Assuming for the moment that $\mathrm{z}$ and $\mathrm{x}$ are parallel, There being no order of degree $\left(z_{1}\right.$ and $\left.z_{2}\right)$, (If $x$ and $y$ and $I$ and 2 are "degrees") Nor, if there were, a good connection between them Like that between $x$ and $y$ (or $y$ and $x$ ), By the very nature of $z$ and the nature of its flowering, As discussed above and as not discussed above. Aside from the fact that $x$ and $y$ are distinct, At least in form, from each other and speaking of one, And what its aspects are and what its divisions, It is not the other, and that of course goes for divisions, Which answers the question (nine above) of degrees.

Or put the other way, the whole other way, There is no concentration or complex thickening In $\mathrm{x}$ or $\mathrm{y}$, or what we call $\mathrm{x}$ and $\mathrm{y}$, To balance what is in $z$, or what we call $z$, Taking $z$ as the original point of congestion. It would be simple if $\mathrm{z}$ and $\mathrm{x}$ were identical And whenever $x$ prevailed then $z$ prevailed And $x$ prevailed only, and always, as $z$ As opposed to $y$, which would be the state without $z$, Or the state without $\mathrm{x}$ since $\mathrm{x}$ and $\mathrm{z}$ are the same, And there is no $x$ and there is no $z$ but in name, Or there is no difference in either name or nature, But $\mathrm{z}$ has a life, $\mathrm{z}$ is not $\mathrm{x}$, nor is $\mathrm{x}$, (Which is saying another thing altogether), as $z$, But has a life of its own transcending $z$, (But, what is worse, a part of it growing out of $z$ ), 
Nor (and another thing altogether) is $\mathrm{Z}$

Related to $\mathrm{x}$ as $\mathrm{z}$ is related to $\mathrm{y}$,

Which could be the fault in $\mathrm{x}$ or $\mathrm{y}$ or $\mathrm{z}$,

Both or either, in the natures or the connections.

A list from one to two hundred ninety-nine

Of what the starved and beaten Pineys were symbols of

Or some of the states or figures seen in the symbol

With no attention at all to the question of precedence.

I. The symbol of stone-like, impersonal power.

2. The opposite, mean vindictive destruction.

3. The tender goat of spite and spleen.

4. The archetype hare, magician of the species.

5. A simple reversion to lower forms.

6. The painless exotic escape from the body.

7. Rot and rust. 8. Splintering.

9. The past: the lips (or teeth) of the past.

Io. Non-being, located in the center.

I I. Non-being, located at the periphery.

I2. Pity. I3. Guilt or torpor.

I 4. Aggression. I 5. Strength and stupidity.

I6. Remoteness. I7. The Cypriot cloud.

18. The Ark. I9. Caves and tree-tops.

20. Blindness. $2 \mathrm{I}$. Immoral passion.

22. Contemplation. 23. Stupid division.

24. Animal existence. 25. Vegetable.

26. Humor. 27. Adult humor.

28. Hatred. 29. Demoniac energy.

30. Intellectual calm. 3I. Despair.

32. The unknown future. 33. Strabismus.

34. Self-control. 35. Spengler.

36. The Little King. 37. Persia.

38. Cloud machinery. 39. Phantasy.

40. Stubborn production. 4I. Pokeweed.

42. Wordsworth's boyhood. 43. Surgery.

44. The Heb-sed festival. 45. Pascal. 
46. Self-promotion. 47. King Zoser.

48. Mixed marriages. 49. Strict discipline.

50. The Final Solution. 51. Ethics.

52. Cemetery A. 53. Paradise.

54. Withdrawal. 55. The learned astronomers.

56. Bad judgment. 57. Albert M. Greenfield.

58. Liberal hyprocisy. 59. Genetics.

60. Technological unemployment. 6r. Senility.

62. The blue Mediterranean. 63. Henry Frick.

64. Degeneracy. 65. The Rules Committee.

66. Sacred coupling. 67. Delinquency.

68. Talleyrand. 69. Perversion.

70. Simple regret. 7I. Government artists.

72. Alabaster. 73. The weavers.

74. Mere contingent empirical existence.

75. The worm. 76. The organization.

77. Techniques and systems. 78. Ritual.

79. The split. 80 . Escape from the split.

$8 \mathrm{I}$. Anesthesia as exclusion of alternatives.

82. Anesthesia as simple exclusion of life.

83. Thurlow Weed. 84. Massa confusa.

85. Boies Penrose. 86. The Fiend.

87. General Babcock. 88. Free love.

89. Bernard Baruch. 90. The Tremendum.

91. Archie Butt. 92. Geographic sprawl.

93. Mrs. Galt. 94. The architect of the future.

95. Professor Berle. 96. The loss of mystery.

97. Drew Pearson. 98. Otto of Roses.

99. Article II. Ioo. Cincinnatus.

IOI. Sherman Adams. IO2. Juba.

I03. The natural existence of incompatibles.

I04. War. I05. Simple disjunction.

I06. The spoiled herd of Ortega y Gasset.

I07. The peevish and forgotten. I08. The manic.

I09. Autonomous hair and skin of the innards.

I IO. Possessions. I I I. Strict objectivity.

I I2. The ineffable. I I3. Meat-eating horses.

I I 4. Spots and blurs. I I 5. Sugar. 
I 6. The evil faun or the faceless knight.

I I 7. The eighteenth century. I I 8. Pollution.

I I 9. Indecision. 120. Descartes.

I 2 I. Deep humiliation. I22. Cannibalism.

I23. Protestant piety. I24. Pandemonium.

I 25. Levitation as passionate striving.

I 26. Levitation as heroic submission.

127. Delusion. 128. The crown of glory.

I29. The Ph.D. I 30. Necrophilism.

I3I. The sense of time. I32. The other.

I33. Paul the ascetic. I34. Ducky Kaufman.

I35. Artemis. 136. The tattooed child.

I37. The liar. I38. The liar in bed.

I39. The false reunion. I40. The heart attack.

I4I. Immediate gratification. I42. Sleep.

I43. Freedom from collision and freedom from suit.

I44. Tenure. I 45. The Committee of Public Safety.

146. Sorrow and ignorance. I47. Karma.

I 48. Proust in his teacups. I49. Slavery.

I 50. Burning documents. I5I. The honeymoon.

I 52. Regeneration through walking and climbing.

I53. Regeneration through separate breathing.

I 54. Regeneration through cheap upholstery.

I 55. Winged creatures. I 56. The Law.

I 57. Free insurance. I 58 . Uproar.

I59. Temporary insanity. I60. Poverty.

I61. Toil. I62. The Malachamovis.

I63. Congenital syphilis. I64. Patience.

I65. Emotional excitement. I66. Irony.

I67. Compound interest. r68. Chastity.

169. Weekly visits. I 70. Destiny.

I71. The formal cause. I72. Mortgage.

I73. The swerve. I74. Immanuel Kant.

I 75. Annihilation. I76. Leaky.

I77. Tortoise interruptus. I 78 . Confusion.

I 79. Justice. I 80. Logic or reason.

I8I. The ocean. I82. The secret room.

I83. Averell Harriman. I84. Jimmy Durante. 
I 85. The Social Register. I 86 . The Cleveland Trust Bank.

I 87. The Morgan Investment Group. I88. The Mellon Interest Group.

I89. The International Detective Agency. r9o. Phillips Exeter.

i91. John Glenn. I92. R. C. Cola.

193. Charity drives. I94. Sears.

195. Beth Israel. r96. Social mobility.

197. The Knickerbocker Club. I98. Pew Memorial Trust.

199. The Rockefeller Foundation. 200. Tree pie.

2OI. Nudism. 202. Richard Wagner.

203. Saliva tests and sanity tests.

204. The ground. 205. Wind or enlightenment.

206. The sense of permanence. 207. The tub.

208. Heat and/or shivers. 209. Alcohol.

2 IO. Evil companions. 2 I I. Napoleon.

2 I 2. Cravings or crazes. 2 I3. Overflowing.

2I4. The N.A.M. 2 I5. Shantih.

216. Error. 217. Hemophilia.

218. The police. 219. Benjamin Franklin.

220. Narcissism. 22I. World War I.

222. The balance sheet. 223. Stalin.

224. Smog. 225. The melting pot.

226. Nominalism. 227. The unfathomable.

228. Romantic agony. 229. The team.

230. The super ego. 23I. Dyspepsia.

232. The machine. 233. Hostility.

234. Mass deportation. 235. The storehouse.

236. Love. 237. Collaboration.

238. Public opinion. 239. Happiness.

240. The lost chance. 24I. Duty.

242. Waste. 243. Insecurity.

244. Adjustment. 245. Common sense.

246. Impatience. 247. Market Street.

248. The foretaste. 249. Protoplasm.

250. Silence. $25 \mathrm{I}$. The means to an end.

252 . Shame. 253. The undifferentiated.

254. Ambiguity. 255. The breast.

256. Nepotism. 257. Yankee larceny. 
258. The Furies. 259. William Jennings Bryan. 260. The common enemy. 26r. Overpopulation. 262. Conflict-of-interest. 263. Hysteria. 264. Class privilege. 265. Stuttering. 266. G. B. Shaw. 267. Corporal punishment. 268. Sturm und Drang. 269. Eternal frivolity. 270. The state. 27I. Spiritual goods.

272. Marcus Aurelius. 273. Linguistics. 274. Corporate control. 275. Percy Shelley. 276. The pork barrel. 277. Gnosticism. 278. Inner space. 279. Operatic display. 280. Job. $28 \mathrm{I}$. Consensus.

282. Small businessmen. 283. Satyrs. 284. Cardinal Spellman. 285. Blood poisoning. 286. American Pioneer Life. 287. Angelo Brutto. 288. Obscene literature. 289. Deuteronomy. 290. The drive for markets. 29I. Voluntary death. 292. King Saul. 293. The horror trip. 294. The hatred of form. 295. Lobotomy. 296. Ozymandias. 297. Vice-president Burr. 298. The Elks. 299. Unconditional surrender.

As I see it now, distinction must be made In kind between the two Houses, $\mathrm{x}$ and $\mathrm{y}-$ This is a stronger position than I took aboveAnd the first must not be seen so much as a likeness Of the second but as its opponent, and even destroyer. If this is the case, though $x$ is not $z$, the White House ( $\mathrm{x}$ ) must either be represented as $\mathrm{z}$

Or a new symbol ( $v$ ) be found to uncover The hopeless and senseless connection of $\mathrm{x}$ and $\mathrm{z}$, Or $\mathrm{x}$ perhaps must be seen as the melting-ground Of $\mathrm{y}$ and $\mathrm{z}$ and $\mathrm{z}$ and $\mathrm{y}$ are the opposites, Or $v$ and $y$, or perhaps now $v$ and $w$; Or $\mathrm{z}$ and $\mathrm{x}$ are the alternate bodies of $\mathrm{y}$, Though not, in this case, the twins, or even parallel; 
Or $\mathrm{x}$ must be seen as a special kind of destroyer

In whose opposition to $\mathrm{z}$ its $\mathrm{y}$ is destroyed,

Even if destruction is in the name of $y$,

If, altogether, the $y$ belongs to the $\mathrm{x}$,

Or belongs to $x$ any more than it does to $z-$

If there is a $y$ at all - the real point of terror.

-I am troubled anyhow by my list of numbers,

Troubled by the quarrelsome uses of the image,

Troubled by the lack of interconnection,

And hope, or hoped, to find some sane solution

In a new arrangement of v's and u's and w's;

The question of course is what am I trying to save.

A dozen times, in the preparation of my list,

I already saw, or foresaw, a part of the problem;

It is not, it is not, the "black, destructive, and cunning"

That eats into the White House, not "wolves and spiders,"

Or not them alone, or "black, destructive, and cunning"

Must be the description not of spiders and wolves,

Or not them alone-the brain, the brain in its lushes

Eats up its own puzzled cells, the brain in its trenches

Destroys through its own perversions its own puzzling meshes,

Or operates out of a fluke or out of a weakness,

And in its luscious operations the dove and the lamb

As well as the wolf and the spider eat and are eaten.

Perhaps it is here that the unconnected symbol

Of the Piney and the owl have a starting point or meeting place,

As travelers meet in a haven or a temporary hell

(As heroes meet in a tree or a gorge or a river)

With nothing in common, not even the thrift communion

That romance of setting-heaven or hell-engenders;

Or perhaps I needed an owl in the (painted) White House

Instead of a broken, charred and slandered Piney

To indicate the good glint of illumination

As well as the comic dearth and perfect murkiness

As well as (remember!) the simple ripping and tearing-

Aside from the fact that the owl was the bird $I$ followed

In stupid unvarying unswerving dull monotony,

Year after year, fall by melancholic fall- 
By default at first, like half the others, but finally

Out of limitation and laziness and simple-mindedness,

Watching, always watching, and smarting, in unordained weakness

While the others bit and scratched and warmed each other

In sweet activation of the brain's dark fissures and furrows,

In (bloody) fake Gothic and pseudo-Byzantine burrows.

\section{4}

Life has been simplified by the murder of the president.

The most comic of all plots has now been revived

And my imagination has spilled into the streets.

The watery poets of our century have had the pleasure

Of peacefully digesting their delectable tropes-

Some have grown fat discussing their morbid youth-

But I have had to look at my own violent image

Come loose from its coil, as in the bafflement dream,

And move, to my terror, according to its own authority.

It is the sluggish one from the bottom of the heap,

So dull that I have rejected it over and over.

For three strange days, between the murder and the burial,

There was no distinction between the crazed and the uncrazed

Nor any more sense in true states than in shadows.

This whole weakness and shame of ours was disclosed

As the one world merged helplessly into the next.

It was as if a horror could be transplanted

With no effort from one location to another.

The benefactors were scandalized and shaken;

There was at once a ludicrous search for safety

And a desperate call to generals, theologians and philosophers.

I, who should have known, found myself stupidly outwitted

By the insanely simple and conventional mind of the murderer

Who had lost, evidently, any deep respect for proportion. 
PART Four

In April, 1963, when the yearly fires

Burned county after county and, this time, because of the size,

Broke onto the screen as stock exotic disaster-

With background music by Wagner and Tchaikovsky-

I thought somehow with relief and security

Of the Plains which owe their pitiful life to fire.

(Lutz, Pinchot, Gifford, Stone, Harshberger.)

For four or five days running the Bulletin and Inquirer

Gave up the Cuban, Negro and Teamster crisis

To roam with peace and comfort in fiery New Jersey.

On the third day, April twenty-second, New Jersey

Declared a state of emergency and Governor

Ozzard, acting in the absence of Governor Hughes,

Who was in Bermuda for the Governors' Conference,

Issued a proclamation which set harsh penalties

For anyone setting a fire in rural areas.

The fires were the worst in New Jersey's history.

288,000 acres were burned

And an army of more than 20,000 men

Was organized and equipped as fire fighters.

The damage was due to a trick unhappy combination

Of extreme drought and heavy changing winds.

Hundreds of homes and buildings were destroyed,

Cities were threatened, major roads were closed,

And giant housing developments put in panic.

Batsto, Hammonton, Elwood, Folsom, Newtonville,

Buena, Mizpah, Mays Landing, Weymouth, Egg Harbor,

Chatsworth, Mt. Misery, Red Lion, Browns Mills, Indian Mills,

Cassville, Smithberg, Lakewood, Toms River, Waretown,

Berlin, Atco, Cecil, Medford, Sweetwater-

All the familiar names of my Elephantiad-

Were either threatened, damaged or ruined by the fires.

Finally, after five days of smoke and fear,

As the flames spread to the shores of Barnegat Bay 
On the one hand and the flats of Camden on the other, The ironic spring rains came and ended the evil.

For my part, I bullied the screen and read the papers

With pencil and scissors, I had grown such a patriot, And every free chance I had I went to the Pines

To look at the damage and study the sad recovery,

But mostly my mind was on the baby Plains,

Those two odd little islands of dwarf vegetation,

The only place where fire is not a true terror

But rather the one efficient or moving cause-

And token of what the Pines in total combustion,

With utter bad luck, with neither rain nor charity,

Could come to be, in the burn as in the aftermath;

And this was my protection and my security,

As well as my death's-head madness and fascination.

The East Plains, I discovered, were wholly untouched,

They were so lucky, this time, in the murderous wind.

The dense scrub oak and pine were green and silent,

The ground was buried in leaves and fallen branches

And in the midst of the thicket the senses were choked

By the heat and lack of air, which is the virtue.

But the West Plains, east of Chatsworth and south of Woodmansie,

Just at the Burlington-Ocean County line

Where 72 cuts across to Long Beach Island,

These were completely, and grossly, destroyed by the fire

Which must have gone through them without the slightest interruption.

Here the trees, or stems, were black and leafless

And the charred sand free of either litter or mold.

The grey cones hung like horrible ornamental balls

Or little mock eggs in the boughs and little tufts

Of rusted needles still clung to the dried-up branches.

In the thicker groves the curled burned-out pine leaves

Built up a thin black mat on the dirty sand,

And near the highway, at one of the solemn crossroads

That are a take-off on our clean intersections, 
A few old dark brown bottles and rusted cans Survived as a kind of shrine to simple loveLove in the heart of the secret unused woods Where neither the dog nor his trooper could spoil the feast.

I forced my way through the thicket among the skeletonsThey seemed like sticks that were planted loosely in the sandAnd though, as always, the tangle was hard to walk through, The pressure was that of dreary supplication And not the living, if unhealthy, closeness I felt two hours before in the other Plains, And the feeling of being engulfed was absent entirely. I broke the trees in two or snapped off limbs With one hand while I protected my eyes with the other. Within a few minutes my skin was black from the soot And my shirt and pants were neatly striped from the branches. It was a perfect find for the Gothic soul;

There was no sound of bird, no trace of lifeEven the anxious mosquitoes were gone-no wretched Imaginary frozen Piltdown forest

Or scarlet boulder land of either Hell Could be the equal to this in pure morbidity, And it was here that secretly and guiltily I broke a stick and traced in a valley of sand, Between the dead trees, an image of the White House, With doors and porticoes and stately windows, And little terraces and sandy walks, And a tiny twig of a man nearby for perspective. God knows the complexity of my feelingsThe range of confusion-from mockery to fear To veneration to affection to simple vexation; I think I knelt in the sand for half an hour Digesting the humor and strangeness of my design.

After this I quickly walked through the woods To find the end of the burn and climb the ridge That marks the southern border of these plains. This ridge, like others in the Pines, though narrow and low 
By any comparison, is still a barrier

Because of the general flatness of the surface,

Even a kind of mountain, with grand slopes,

And a dividing line between two types of communities,

Like the cedar bogs that follow the line of the streams,

Transition on one side, Plains growth on the other.

Lutz even refers to "mountain ranges,"

Although the elevation above sea level

Is less than two hundred feet and the rise maybe sixty.

There was no mistake in Lutz (or Stone or Harshberger).

The fire ended on the northern slope of the ridge

And above the fire line the growth was normal.

Half way up, and not in this case coterminous

With the fire line, the thicket was converted

Into a stretch of open space which strengthened

The curious sense of elevation; the bushy

Scattered dwarfs, demented by their exposure,

Were loaded with hard green cones and the ground was covered

With blooming laurel, arbutus and huckleberry.

Facing east, the char, to my left, was a large

Black scar as far as the line some two or three inches

Above the telephone wires on route 72 ,

But to the right, to the south, the color survived,

With ashes here and there, in complex waves

Of greys and greens, a delicate interlacement

Produced by sudden changes in height and density.

The floor was a deeply-pitted coarse white gravel.

I lay on the ground for hours in perfect luxury,

Watching birds and studying life signs in the sand.

Part of my pleasure was derived from the height,

Although it was too low for true euphoria,

And part of it lay in the absence of any burning.

There was no new curiosity in this,

Nor did the presence, or the height or the shape, of the hill

Have anything to do with escape or survival.

Truth, at times, in spite of the nourishing air, 
My brain slipped and I saw this pleasant ridge

As Insane Mountain, myself as Heady Keeper,

Or out of blasphemy or fake civility

I turned my bitter gums on the dear mountain peaks

Of Greece and Palestine and saw myself

As Playful Penitent or Coy Defector,

Or in the mood of interstellar gluttony

I turned to tenderness and saw myself

As the last of the Rebels or the first of the True Believers,

There is such comfort in throwing away that Europe

And such delight in all that root-like suffering,

The three of us, the sun and me and the cave-

But all that was only in passing and mostly I thought

Of the contrast between the ridge and the burned-out forest,

Simply the contrast between the ridge and the forest,

(I am allowed this pleasure after thirty-eight years)

And the possibility of life that was then admitted

Without sanctifying the poverty-or tenderness-of the Plains,

Which burned out of drought and wind and simple neglect,

And the ridge that was saved by height and lack of cover.

After this I walked away from the hill

And back to the car at the little intersection of love

And back to Philadelphia through Medford and Camden.

My poem was over now except for the writing

Of the last two sections and the final painful niceties

And this was the last of my critical visits to the Pines.

As I drove up Vine Street past the hydropic bums

Gathered in quiet little groups for the hour of reason

Before the opening of the Christian kitchens,

I felt a quaint touch of sadness for Philadelphia,

That old and ugly city where I had passed

Those seven good years between the tongue and the nippers

And seen the birth at last of my tender ghost,

And which I was leaving now at the end of an Age.

I took the East River Drive instead of the Deathway

For a last slow look at the park and the peaceful river

And arrived home in a lonely melancholic state 
Just as the sun was setting in West Philadelphia.

My wife had polished the windows or killed the spiders

Or done some secret thing to give her that brightness

And the children were clean and quiet as little supplicants.

It was the pure sinfonia domestica,

Complete with tubas and bittersweet violins,

And I was in an unctuous clumsy bind-

My lobate arms stretched on the bloodless grid-

In the face of their delicate trills and pretty glisses.

It took ten minutes at least for the room to settle

And the blood to return, and during that time, while their voices

(In soft percussives) occupied the background,

I saw I think it was Wilson pounding on the windows,

T.R. at the frames, F.D.R. at the sashes,

Lincoln and Washington manning the two white pillars,

Adams, Jackson and Jefferson crowding at the door

And others pushing up the steps or climbing the rails

In a really grotesque, and preposterous, frontal assault.

They all had about them an air of fantastic dignity

In spite of the absurdity of their situation

And only occasionally grinned with embarrassment.

They wore ridiculous costumes-silk hats, slippers-

According to the period of their ascendency

But obviously ill-fitting and old and dirty,

And seemed to me like the flotsam of sinister agencies

Looking for the next meal or the next drink

In the style of cashiered actors and hydropic bums.

They moved around on the porch in little groups

And looked at each other for their cues as if the plan

Of attack was only partly fixed, or depended-

What is worse-on their own resources and changes of luck;

And sometimes they took to moaning like frustrated deefies

And sometimes they would lose their great dignity

And fall to whooping or bend their heads and weep-

The ones without beards were painted white and the hair

On the others was false - the whole thing was outrageous-

And I strained my eyes to see the secret explanation,

Then blinked them to dispel the vision in water, 
Then crossed them to dispel the vision in chaos,

Then closed them to dispel the vision in mind

And let the good lamps of evening filter the horror

As, room by room, the shrieking fellowship of light,

Pushing the buttons and pulling the chains and tassels,

Plunged the house in blazing ferocious incandescence.

\section{NOTES ON CONTRIBUTORS}

Richard Hazley is a poet and member of the English faculty at Indiana University of Pennsylvania.

Gerald Stern, a native of Pittsburgh, $\mathrm{Pa}$., has taught at various colleges and universities; he is presently on the faculty of Somerset County College, N.J. Some of his recent poems will be published in the Spring issue of The Sixties. A portion of "The Pineys" appeared in Genesis West. 